\title{
Reasons for the Outflow of Library Teachers in Private Colleges and Its Countermeasures
}

\author{
Changying Huang \\ Fuzhou University of International Studies and Trade \\ Fuzhou, China
}

\begin{abstract}
The education of private colleges in China flourishes as time goes on, promoting the social and economic development. Private colleges are inclined to neglect library. The outflow of young core library teachers is serious, which endangers the long-term development of libraries. This paper states the omen and risk of the outflow of library teachers in private colleges, analyzes the reasons and proposes countermeasures, in order to make libraries in private colleges better retain talents and promote its construction.
\end{abstract}

Keywords—private colleges; library; outflow; countermeasures

\section{OMEN AND RISK OF OUTFLOW OF LIBRARY TEACHERS IN PRIVATE COLLEGES}

\section{A. Omen of the Outflow of Library Teachers in Private Colleges}

According to the observation of job performance of library teachers in private colleges before demission, some experienced human resource management experts find most library teachers often have negative job performance and abnormal behaviors before demission. We call it "omen of the outflow of library teachers".

1) Negative job performance: When some library teacher decides to leave a school, he often holds a negative attitude towards work. Because an idea deep inside has occurred, "I will leave this school before long, so I have no need to make all-out efforts for this job that will not belong to me". It will make the outer emotions of these teachers greatly change. Therefore, he will hold a negative attitude towards job. Library leaders can observe it with ease.

2) Abnormal behaviors: Some scrupulous library leaders in private colleges will observe the abnormal behaviors of some library teachers recently. For example, some library teacher answers private phone and often look around cautiously when answering it. The key contents of conversation are abnormal. It is because he does not want to be fired before finding a new job.

\section{B. Risk of Outflow of Library Teachers in Private Colleges}

The outflow of excellent library teachers may bring losses for school library. The direct consequence is an increase of labor cost of this post, because the school needs to recruit and train anew. It leads to bigger indirect losses like the delay of job schedule and poor teaching effects.

\section{REASONS FOR OUTFLOW OF LIBRARY TEACHERS IN PRIVATE COLLEGES}

\section{A. External Reasons for Outflow of Library Teachers in Private Colleges}

1) Influence of peak season for job hunting: Human resource managers in many private colleges find when the school has to recruit a large number of new employees, excellent library teachers resign at this time. It makes them feel confused and helpless. Therefore, they have to recruit new teachers at the same time handle check-out procedures for these library teachers. In reality, the phenomenon embodies the characteristics of peak season for job hunting.

2) Influence of external pressure: Some library teachers perform well and never show their discontent towards the internal management of school and library and the complaints of leaders or never lack confidence in the prospect of the school, but they submit the resignation all of a sudden and firmly. They are influenced by external pressures. According to the analysis of some HR experts, it indicates some library teachers don't want to resign, but when they see other library teachers have successful job-hopping and get higher pay and better development, and their intimates arouse and exert pressure, they will compare unconsciously. If they think they are more competent than those with successful job-hopping, they will job-hop.

3) Employment in other schools: Many schools pay attention to the employment of library teachers to have richer human resources. Generally speaking, schools recruit library teachers required before summer vacation, in order to have a fresh start more energetically in the upcoming new school year.

\section{B. Internal Reasons for Outflow of Library Teachers in Private Colleges}

Compared with external reasons, internal elements of schools are the root cause for outflow of library teachers. It is generally assumed that the internal reasons include:

1) Feel dissatisfied with the salary: In terms of the salary situation of most schools, the discontent with salary becomes one of the most important internal reasons for outflow of library teachers. If the overall salary of library teachers is lower than the average level in schools of the same kind, or some library teachers feel the salary cannot meet the basic 
living needs, once they find other schools or enterprises can provide higher salary, they will resign. Furthermore, the comparison of salaries among library teachers also causes the outflow of library teachers. The equity theory proves library teachers have a sense of unfairness when they find other library teachers with the similar competence have higher salary. They will resign when appropriate opportunity exists.

2) Object to the management of private colleges: The outflow of library teachers has obvious relationship with school leaders and their management style. According to the archival records of the resigned library teachers in HR department, $40 \%$ to $50 \%$ of library teachers resign with reasons like inadaptation to the job and poor health. In reality, the most direct reason is library teachers' objection to the character and style of leaders. It leads to the resignation of about one third library teachers. The resignation of library teachers is because they are strongly dissatisfied with some leader (direct leader of them) or the whole management layer. We conclude it as objection to school management.

The internal management mechanism of school or the management style of some leaders significantly influences library teachers' job morale and working enthusiasm. If a few library teachers fail to adapt to the internal management mechanism or object to the management style of some leaders, they often carry out self-adjustment; but if most library teachers feel dissatisfied with the school management, they will think this is not their problem and refuse self-adjustment. As time passes, they cannot work wholeheartedly and fail to feel a sense of achievement. At last, they will solve the contradiction via resignation.

3) Lose confidence in the prospect of private colleges: Excellent library teachers or library teachers eager to development pay special attention to the development prospect of schools, especially in private colleges, because they know they will have sufficient development opportunity and broad development space with the development of school. If the school has obscure prospect, library teachers will lose confidence in it and resign sooner or later. The lack of confidence in the development prospect of school is the significant cause for the resignation of competent and welltrained library teachers. They are eager to show talent in places with broader development space.

4) Feel inadaptable to campus culture: The influence of campus culture on outflow of library teachers is penetrative, complicated and should not be neglected. Campus culture and cultural atmosphere reflect the influence of a school. Schools without influence will not have strong cohesion, leading to the huge outflow of library teachers.

\section{COUNTERMEASURES FOR OUTFLOW OF LIBRARY TEACHERS IN PRIVATE COLLEGES}

HR managers and administrators at all levels in private colleges should take effective measures according to external and internal reasons, in order to control the outflow of library teachers.

\section{A. Guarantee the Position and Increase the Salary of Library Teachers}

Excellent library teachers are final guarantee of working quality of private college library as well as the core power of school management. Schools should "carry out human resource planning, increase the salary of library teachers to reduce the outflow of excellent library teachers". Private colleges should adhere to "people-oriented" management concept, increase the salary of library teachers and protect primary interests of them like job title, social insurance and medical insurance as well as create the environment conducive to the growth, work and mentality of them, respect library teachers to let them retain willingly.

\section{B. Confirm the Career Planning of New Library Teachers}

The confirmation of career planning should start at the beginning of employment of library teachers. However, it cannot finish in one step but goes through a procedure from vague to clear, random to reasonable. HR managers in schools should help library teachers to make career planning step by step.

The confirmation of career planning is progressive and bases on the major and the strong points of library teachers. In career planning of library teachers, schools should base on the major and the strong points of library teachers, in order to fully tap their potential and advantages.

\section{Create the Culture that Cares for Library Teachers}

From the perspective of human resource management, all leaders in the school are amenable to pay close attention to work and mental changes of library teachers, give supports and guidance at any time and take essential countermeasures. Besides, schools should proceed from the whole situation, roundly care for the work and life of library teachers and let them feel warm in school.

The care for library teachers is more an investment than a dedication. When library teachers feel it, they will work with more enthusiasm. The long-term development of schools has close relationship with enthusiasm and loyalty of library teachers who will not easily resign after they feel the warm in school and take school as their home.

\section{Strictly Control the Recruitment}

The recruitment of new library teachers is a distinctly important link of human resource work in private colleges. Successful recruitment will make the subsequent human resource management smoother. If the recruiter can have an indepth and comprehensive understanding of applicants in the recruitment, the school may furthest avoid the outflow of library teachers in the future.

Private colleges shoulder heavy responsibilities in the development of library. In order to retain professional library talents, staff in private college libraries can increase salary of library teachers, confirm the career planning of them and create culture favorable to library teachers as well as strictly control the recruitment. 


\section{REFERENCES}

[1] Wu Hanhua, Zhang Fang. Analysis on Current Situation of Human Resource in College Library of Our Country [J], Journal of Academic Libraries, 2015(03): 43-50

[2] Hui Ling. Application of Benchmarking Management in Allocation of Library Personnel in Independent Colleges [J], Talent Resources Development, 2015(09): 23

[3] Li Baoquan. Analysis on Improvement of Quality and Ability of Staff in Library [J], Journal of Jiaozuo University, 2015(12): 127-129 